\title{
DINAMIKA MODAL SOSIAL DALAM PEMBERDAYAAN MASYARAKAT PADA DESA WISATA HALAL SETANGGOR: KEPERCAYAAN, JARINGAN SOSIAL DAN NORMA
}

\author{
Vidya Yanti Utami \\ Sekolah Tinggi Ilmu Administrasi Mataram \\ Email: vidyautami88@gmail.com
}

\begin{abstract}
Abstrak: Penelitian ini dilatari konteks ekonomi yang terjadi pada masyarakat Desa Setanggor di Kabupaten Lombok Tengah. Hasil panen yang biasa mengalami penurunan tiap kali terjadi musim kemarau karena sawah-sawah tidak bisa ditanami menyebabkan sebagian besar penduduk laki-laki yang memiliki mata pencaharian sebagai petani hanya menganggur. Melihat potensi besar yang dimiliki oleh Desa Setanggor, Ida Wahyuni seorang anggota masyarakat Desa Setanggor, mempelopori dengan memanfaatkan modal sosial yang ada pada masyarakat Desa Setanggor. Penelitian ini bertujuan untuk mengetahui dinamika modal sosial dalam pemberdayaan masyarakat dan dampak yang dirasakan bagi masyarakat Desa Setanggor. Penelitian ini menggunakan metode penelitian kualitatif dengan pendekatan studi kasus. Hasil penelitian menunjukkan bahwa modal sosial yang kuat yang dimiliki oleh masyarakat Desa Setanggor mampu mengatasi permasalahan yang terjadi. Berhasilnya pemberdayaan yang terjadi di Desa Setanggor menciptakan aktivitas ekonomi baru yang dikemas menjadi Desa Wisata Halal. Keberhasilan Setanggor dalam memberdayakan masyarakatnya, melalui sejumlah dinamika modal sosial. Modal sosial yang ditemui tersebut berupa kepercayaan, jaringan sosial dan norma.
\end{abstract}

Kata kunci: Modal Sosial; Kepercayaan; Jaringan Sosial; Pemberdayaan Masyarakat; Desa Wisata

Abstract: This research is motivated by economic problems that occur in community of Setanggor Village, Central Lombok Regency. Yields that are usually reduced during the dry season because the fields cannot be planted, so that most of the male population who have a livelihood as farmers are just unemployed. Seeing the great potential possessed by Setanggor Village, Ida Wahyuni as a Setanggor Village community pioneered by utilizing the existing social capital in the Setanggor Village community. This study aims to determine the dynamics of social capital in community empowerment and the impact for the community of Setanggor Village. The results showed that the social capital owned by the community of Setanggor Village was able to solve the problems that occurred. The successful empowerment that occurred in Setanggor Village created a new economic activity that was packaged into a Halal Tourism Village. The success of Setanggor Village in empowering the community, through some dynamics of social capital. The found social capital in the form of trust, social networks and norms.

Keywords: Social Capital; trust; Social Network; Community Empowerment; Masyarakat; Tourism Village

\section{PENDAHULUAN}

Modal sosial memiliki peran sebagai tenaga penggerak dalam berbagai tindakan sosial. Hal ini seperti yang dikatakan oleh Brehm dan Rahn (Winarni, 2011) bahwa modal sosial dapat didefinisikan sebagai jaringan kerjasama di antara warga masyarakat yang memfasilitasi pencarian solusi dari permasalahan yang dihadapi. Peran modal sosial dapat menyerahkan tanggung jawab kepada individu dalam suatu kelompok yang kemudian akan memunculkan keeratan antar kelompok masyarakat yang lebih efisien sehingga permasalahan yang terjadi di masyarakat dapat terselesaikan (Yustika, 2013). 


\section{REFORMASI}

ISSN 2088-7469 (Paper) ISSN 2407-6864 (Online)

Volume 10 Nomor 1 (2020)

Desa Setanggor terletak di Kecamatan Praya Barat, Kabupaten Lombok Tengah, Provinsi Nusa Tenggara Barat. Dengan luas wilayah 676 hektar, desa ini memiliki kekayaan sumber daya alam seperti areal persawahan seluas 483 hektar yang terbentang indah. Namun desa ini tergolong ke dalam desa yang sering mengalami kekeringan disaat musim kemarau tiba. Hasil panen masyarakat Desa Setanggor mengalami penurunan karena sawah-sawah mereka sebagian besar tidak bisa ditanami, sehingga sebagian besar penduduk laki-lakinya hanya menganggur saat musim kemarau tiba.

Jumlah penduduk Setanggor sekitar 4.065 jiwa. Sebanyak 80 persen penduduk perempuannya memiliki keterampilan menenun kain songket, sehingga desa ini menjadi produsen kain songket khas Sasak di Lombok. Namun sudah lama mereka tidak lagi menenun karena kesulitan untuk mencari pembeli yang mau membeli kain songket buatan mereka (Wawancara Awal, 2017).

Desa Setanggor juga memiliki kekayaan seni budaya, seperti adanya kelompok gamelan, seni tari dan drama tradisional. Terdapat benda sejarah seperti gong tua yang sudah berumur ratusan tahun sebagai warisan budaya. Namun, seni dan budaya yang dimiliki sempat terancam pudar karena jarang digunakan. Secara keseluruhan dapat dikatakan bahwa desa ini memiliki potensi yang unik dan daya tarik yang berbeda dengan desa-desa lain pada umumnya, namun menghadapi ancaman gerusan zaman.

Berangkat dari permasalahan tersebut serta melihat berbagai potensi besar yang dimiliki oleh Desa Setanggor, membuat Ida Wahyuni selaku masyarakat Desa Setanggor berusaha mencari alternatif lain untuk meningkatkan perekonomian masyarakat sekaligus melestarikan dan menghidupkan kembali seni budaya yang memang sudah dimiliki oleh desanya, yaitu dengan cara mengemas berbagai potensi tersebut menjadi sebuah "Desa Wisata Halal" yang memiliki keunikan dan ke khasan tersendiri. Kini Desa Setanggor memiliki komunitas pariwisata yang kuat, meskipun pada kenyataannya Pemerintah Kabupaten Lombok Tengah sendiripun pada awalnya menganggap remeh ide/gagasan desa wisata tersebut sehingga kurang mendukung secara materi.

Hal diatas merupakan bukti bahwa modal sosial juga berperan dalam penyelesaian masalah yang terjadi di masyarakat. Namun perlu diketahui bagaimana dinamika modal sosial dalam pemberdayaan masyarakat di Desa Setanggor dan dampak yang dirasakan oleh masyarakat setempat setelah desanya menjadi salah satu desa wisata halal di Lombok?. Oleh karenanya penelitian ini perlu dilakukan secara mendalam, karena prestasi pembangunan desa yang berbasis modal sosial yang kasuistik seperti Setanggor perlu diinventarisir oleh negara sebagai best practice pembangunan desa wisata di Indonesia.

\section{METODE PENELITIAN}

Penelitian ini menggunakan metode penelitian kualitatif, dengan memanfaatkan wawancara terbuka untuk menelaah dan memahami sikap, pandangan, perasaan dan perilaku individu atau sekelompok orang. Penelitian kualitatif dimaksudkan untuk mengeksplorasi dan memahami makna dari masalah-masalah sosial (Creswell, 2010), serta memberi rincian yang kompleks tentang fenomena yang sulit diungkapkan dengan metode kuantitatif (Strauss dan Corbin, 2003). Adapun jenis pendekatan dalam penelitian ini adalah pendekatan studi kasus

Obyek yang diteliti adalah dinamika modal sosial masyarakat di Desa Setanggor dalam pemberdayaan masyarakatnya sehingga bisa terbentuknya Desa Wisata Halal Setanggor yang dijadikan alternatif dalam meningkatkan ekonomi di desa tersebut. Keunikan dan kekhasan objek penelitian menjadi pertimbangan utama menggunakan jenis pendekatan ini. Ada karakteristik sendiri pada lokus penelitian yang membedakan dengan kasus lain. Pendekatan ini dimaksudkan untuk menggali lebih dalam suatu fenomena mulai proses awal sampai akhir penelitian.

Observasi dan wawancara dilakukan sebagai data primer. Adapun teknik yang akan digunakan dalam menentukan sumber data primer atau informan adalah purposive sampling melalui key person. Peneliti akan memilih informan dengan pertimbangan tertentu, di mana informan tersebut memiliki 


\section{REFORMASI}

ISSN 2088-7469 (Paper) ISSN 2407-6864 (Online)

Volume 10 Nomor 1 (2020)

kapasitas dan kapabilitas sesuai dengan kebutuhan data penelitian. Dalam penelitian ini yang menjadi informan kunci adalah Ida Wahyudi selaku Aktor Penggerak Desa Wisata Halal Setanggor, Ketua Kelompok Sadar Wisata (POKDARWIS) di Desa Setanggor, Ketua Kelompok Tani di Desa Setanggor, Kepala Dusun Mertak Seni, Kepala Dusun Mertak Me serta Masyarakat Desa Setanggor yang terlibat langsung dalam pengembangan Desa Wisata Halal Setanggor.

Analisis data dilakukan secara analisis kualitatif berdasarkan data, fakta dan informasi yang dikumpulkan. Dalam penelitian ini, peneliti menggunakan analisis data kualitatif, dengan berdasarkan model interaktif oleh Miles \& Huberman dan Saldana. Adapun komponen-komponen analisis dalam model interaktif ini digambarkan sebagai berikut:

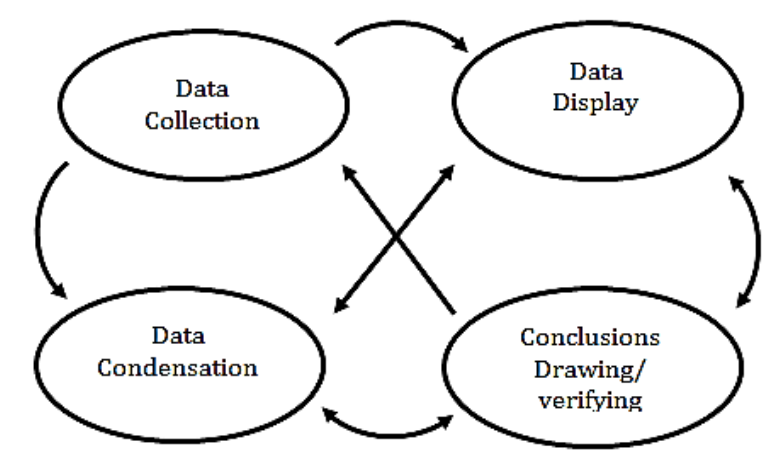

Gambar 1. Komponen Analisis Data Model Interaktif Sumber: Miles, Huberman, dan Saldana 2014

Pada gambar diatas, terdapat tiga alur kegiatan yang terjadi, yaitu (1) Data Condensation (Kondensasi Data) yaitu merupakan satu bentuk analisis yang menajamkan, menggolongkan, mengarahkan, membuang yang tidak perlu, dan mengorganisasi data dengan cara sedemikian rupa hingga kesimpulan-kesimpulan finalnya dapat ditarik dan diverifikasi (2) Data Display (Penyajian Data) yaitu merupakan alur penting dalam kegiatan analisis. Dengan melakukan penyajian data-data, peneliti dapat memahami suatu peristiwa yang sedang terjadi dan tindakan yang seharusnya dilakukan. Bentuk penyajian data yang digunakan adalah bentuk teks naratif, (3) Conclusions: Drawing/Verifying (Penarikan Kesimpulan/Verifikasi). Data dalam penelitian ini dijelaskan secara komprehensif dan diperiksa melalui proses triangulasi demi menarik rangkaian kausal yang paling masuk akal sebelum menarik kesimpilan (Sugiyono, 2009).

\section{HASIL DAN PEMBAHASAN}

\section{Dinamika Kepercayaan, Jaringan Sosial dan Norma dalam Pemberdayaan Masyarakat pada Desa} Wisata Halal Setanggor

Pemberdayaan masyarakat merupakan suatu proses pembangunan dimana masyarakat memiliki inisiatif sendiri atau dari orang lain untuk memulai proses kegiatan sosial dalam memperbaiki kondisi dan siatuasi yang ada dilingkungan masyarakat itu sendiri. Pemberdayaan masyarakat dapat berhasil jika apabila masyarakatnya ikut berpartisipasi dalam kegiatan tersebut. Hal itu dapat terjadi jika modal sosial yang ada dimasyarakat kuat. Modal sosial umumnya dinilai dari interaksi yang terbangun didalam masyarakat. Putnam dalam Yustika (2013), mendefinisikan modal sosial sebagai gambaran organisasi sosial, seperti: (1) Kepercayaan Sosial, (2) Jaringan Sosial, dan (3) Norma, yang memfasilitasi koordinasi dan kerjasama yang saling menguntungkan. Ketiga bentuk modal tersebut saling memfasilitasi koordinasi dan kerjasama yang saling menguntungkan. Menurut Brata (2004) dalam Winarni (2011), modal sosial 


\section{REFORMASI}

ISSN 2088-7469 (Paper) ISSN 2407-6864 (Online)

Volume 10 Nomor 1 (2020)

dapat diarahkan pada persoalan-persoalan pembangunan ekonomi yang sifatnya lokal seperti dalam hal pengentasan kemiskinan yang terjadi di masyarakat.

Melihat berbagai potensi unik dan khas yang dimiliki Desa Setanggor merupakan asal mula dilakukannya pemberdayaan pada masyarakat di Desa Setanggor Kabupaten Lombok Tengah, yaitu dengan mengemas Desa Setanggor menjadi sebuah Desa Wisata Halal. Pemberdayaan yang dilakukan ini sekaligus untuk mengatasi dan mencari jalan keluar dari permasalahan yang terjadi pada masyarakatnya saat itu. Namun, hal tersebut tidak langsung berjalan dengan mulus karena belum terbentuknya sistem kelembagaan yang baik serta kepercayaan yang kuat. Hal ini dapat terlihat dari terjadinya pro dan kontra saat awal Ida Wahyuni yaitu seorang masyarakat Desa Setanggor mensosialisasikan idenya menjadikan Desa Setanggor menjadi obyek wisata yang disebut Desa Wisata Halal Setanggor. Banyak masyarakat yang menolak dan menganggap itu ide yang mustahil karena mereka menganggap desa mereka tidak memiliki potensi untuk dijadikan sebuah desa wisata dan tidak percaya desanya bisa menjadi desa wisata.

Namun hal ini tidak serta merta membuat Ida patah semangat. Ida mengumpulkan tokoh-tokoh adat, tokoh masyarakat, tokoh agama, semua kepala dusun dan kemudian melakukan sosialisasi dan pembinaan setiap minggunya dan mempresentasikan ide nya tersebut dengan memperlihatkan videovideo terkait desa wisata yang mana dapat memberikan gambaran kepada masyarakat. Kurang lebih hingga 6 bulan lamanya, akhirnya Kepala Desa dan seluruh Kepala Dusun dari 14 Dusun berembuk dan akhirnya membentuk pengurus Kelompok Sadar Wisata (POKDARWIS) yang mana pada bulan Juni 2016, keluarlah SK POKDAWIS yang bernama POKDARWIS SEKARTIJE, dengan anggota sebanyak 32 orang dan semua Kepala Dusun masuk didalamnya. Meskipun masih ragu-ragu, namun pelan-pelan masyarakat mulai mendukung dan ikut berpartisipasi. Hingga pada bulan Oktober 2016, mereka launching Desa Wisata Halal Setanggor.

Pemberdayaan yang dilakukan kepada masyarakat Desa Setanggor, antara lain:

1. Membuka cara pandang masyarakat Desa Setanggor dari yang berfikir bahwa desa setanggor tidak memiliki potensi apapun menjadi yakin bahwa desa setanggor memang layak untuk dijadikan suatu desa wisata

2. Meluruskan ketakutan masyarakat akan dampak negatif dari suatu kegiatan pariwisata yang mana semuanya bisa diminimalisir dengan konsep wisata halal.

3. Memberikan pembinaan terkait cara mengelola sebuah desa wisata.

4. Mengajak masyarakat untuk menjaga dan melestarikan potensi-potensi desa nya yg memang sudah ada

5. Melakukan pemberdayaan kepada masyarakat yang terlibat di objek desa wisata dalam melayani wisatawan yang datang ke Desa Wisata Halal Setanggor

6. Memberikan pembelajaran bahasa Inggris kepada masyarakat Desa Setanggor yang terlibat dalam aktivitas Desa Wisata Halal Setanggor agar bisa berinteraksi dengan berbagai wisatawan baik domestik dan mancanegara untuk menunjang pelayanan menjadi lebih baik

Terlepas dari keberhasilan pemberdayaan yang dilakukan, masih terdapat beberapa masyarakat yang belum mendukung dan tidak mau ikut berpartisipasi dalam aktivitas Desa Wisata Halal Setanggor. Sejalan dengan Satria (2008) dimana berpendapat bahwa rendahnya kualitas modal manusia dihampir sebagian negara miskin dan berkembang menyebabkan mereka rentan terhadap perubahan globalisasi yang cepat, sehingga akhirnya larut dan dirugikan dalam proses didalamnya.

Namun hal ini tidak serta merta mempengaruhi modal sosial yang kuat pada masyarakat Desa Setanggor. 


\section{REFORMASI}

ISSN 2088-7469 (Paper) ISSN 2407-6864 (Online)

Volume 10 Nomor 1 (2020)

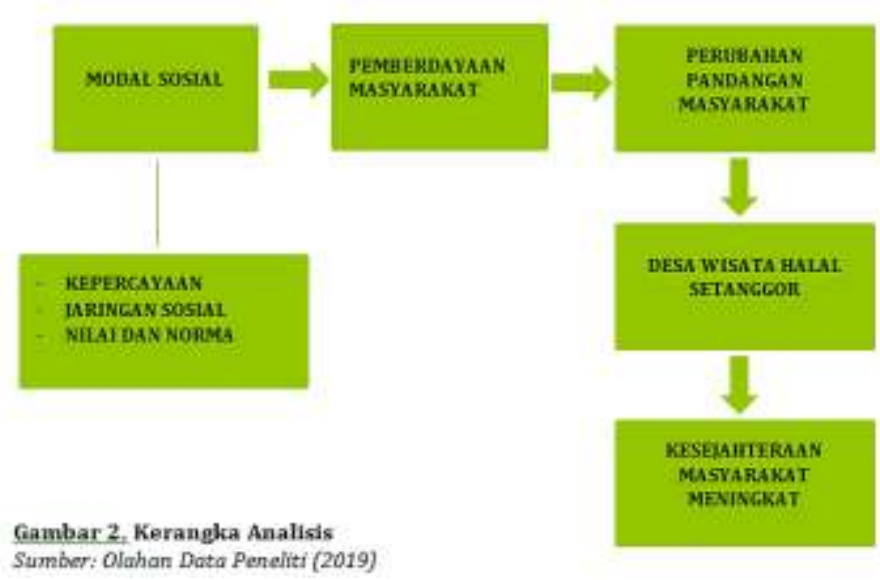

Berhasilnya pemberdayaan yang terjadi di Desa Setanggor, menciptakan aktivitas ekonomi baru yang dikemas menjadi Desa Wisata Halal, yang mana keberadaannya dapat berkontribusi dalam meningkatkan kesejahteraan masyarakat. Keberhasilan Desa Setanggor melalui aktor kunci, Ida Wahyuni, melalui sejumlah dinamika. Modal sosial yang ditemukan antara lain:

\section{Kepercayaan}

Desa Setanggor merupakan desa yang memiliki keindahan panorama alam pesawahan yang terbentang luas dan indah, namun desa ini tergolong kedalam desa yang sering mengalami kekeringan saat memasuki musim kemarau. Sebagian besar penduduk laki-laki Desa Setanggor bermata pencaharian sebagai petani padi dan palawija, sedangkan sekitar $80 \%$ penduduk perempuannya atau bisa dikatakan hampir disetiap rumah yang ada di Desa Setanggor memiliki kemampuan menenun. Namun beberapa tahun lalu, mereka sudah tidak aktif lagi menenun. Hal ini dikarenakan kesusahan dalam mencari pembeli.

Pada tahun 2016, salah seorang masyarakat di Desa Setanggor yaitu Ida Wahyuni tergerak hatinya untuk berusaha mencari alternatif lain untuk meningkatkan perekonomian masyarakat dan melestarikan sekaligus menghidupkan kembali seni budaya yang memang sudah dimiliki oleh Desa Setanggor, dengan cara mengemas berbagai potensi tersebut menjadi sebuah "Desa Wisata Halal" yang memiliki keunikan dan ke khasan tersendiri sehingga dapat menarik minat para wisatawan domestik maupun mancanegara untuk datang berlibur.

Hingga akhirnya dilakukannya pemberdayaan masyarakat. Pemberdayaan yang dilakukan tidak terlepas dari sistem kepercayaan masyarakat Desa Setanggor yang telah dibangun. Hal itu terjadi karena adanya daya tarik yang menyebabkan masyarakat percaya akan ide dari Ida Wahyuni. Hal ini sejalan dengan aforisme terkenal yang berpendapat bahwa modal sosial "bukanlah masalah apa yang anda ketahui, tetapi siapa yang anda kenal" (its not what you know, it's who you know that matters) (Fine dan Lapavitsas, 2004) dalam Yustika (2008).

Membangun kepercayaan di dalam masyarakat merupakan kunci utama dalam modal sosial untuk melakukan pemberdayaan dimasyarakat. Dalam hal ini bekerjasama untuk mewujudkan menjadi Desa Wisata Halal Setanggor. Hal ini sependapat dengan Fukuyama (2002) dimana berpendapat bahwa kepercayaan merupakan unsur yang sangat penting dalam modal sosial karena merupakan perekat bagi langgengnya suatu kerjasama dalam kelompok masyarakat.

Sejalan dengan Fukuyama, Syahyuti (2008) berpendapat bahwa trust secara sederhana merupakan "willingness to take risk" yaitu interaksi yang didasari pada perasaan yakin (sense of confidence), bahwa orang lain akan memberikan respon sebagaimana yang diharapkan dan saling mendukung. 


\section{REFORMASI}

ISSN 2088-7469 (Paper) ISSN 2407-6864 (Online)

Volume 10 Nomor 1 (2020)

Yang terjadi pada desa setanggor. Dimana kepercayaan bukan karena adanya interaksi sosial melainkan kepercayaan yang ada pada masyarakat Desa Setanggor terbentuk karena adanya hasil nyata dari Ide yang Ida Wahyuni pelopori. Sehingga hal itu membuat sebagian besar kepercayaan masyarakat yang sebelumnya tidak mendukung menjadi percaya terhadap konsep Desa Wisata Halal yang di sampaikan oleh Ida Wahyuni selaku pelopor (Agent Of Change).

Kepercayaan tersebut terbangun juga bukan hanya karena Ida Wahyuni adalah salah satu penduduk di Desa Setanggor yang cerdas dan pintar. Melainkan karena masyarakat menilai Ida Wahyuni dapat mengatasi permasalahan atau penolakan yang dilakukan oleh sebagian masyarakat Desa Setanggor dengan kesabaran dan kegigihannya yang terus menurus pelan-pelan memberikan penjelasan terkait gagasannya dan pembinaan untuk menjadikan Desa Setanggor menjadi desa wisata halal yang dapat memberikan berbagai dampak positif bagi masyarakat disana. Ia berjanji jika dalam satu tahun gagasannya tentang Desa Wisata Halal Setanggor tidak dapat memberikan dampak positif bagi kesejahteraan masyarakat disini, maka ia akan pergi dari desa tersebut (Wawancara 2019).

Untuk membangun suatu kepercayaaan yang ada di masyarakat umumnya tidak mudah dilakukan dan membutuhkan strategi serta cara sosialisai yng baik. Masyarakat hanya butuh bukti nyata, pada dasarnya kemauan masyarakat tidaklah ribet. Jika ada bukti nyata yang mereka rasakan dan selagi itu tidak bertentangan dengan norma yang ada di masyarakatnya

Suatu kepercayaan dibutuhkan dalam sebuah kelompok atau masyarakat karena dengan adanya kepercayaan atau trust yang terjalin maka orang-orang yang ada didalamnya maupun diluar kelompok tersebut dapat berekerja scara lebih efektif (Fukuyama, 2002). Adanya high trust yang terjadi di dalam kelompok juga menciptakan solidaritas yang kuat sehingga mampu membuat tiap individu bersedia mengikuti aturan yang ada serta ikut memperkuat rasa kebersamaan dan memiliki.

Hal itu terjadi pada masyarakat Desa Setanggor yang mempunyai rasa memiliki dalam menjaga, melestarikan dan menghidupkan kembali seni budaya yang memang sudah dimilikinya, dan mengemas berbagai potensi yang dimiliki menjadi desa wisata halal.

Sense of belonging yang terbangun merupakan bentuk kepercayaan yang berhasil ditumbuhkan pada masyarakat Desa Setanggor baik yang ikut menjadi pengurus Desa Wisata Halal Setanggor maupun yang tidak. Dimana mereka berkomitmen untuk menjaga kelestarian potensi alam dan seni budaya yang ada di Desa Setanggor.

Komitmen masyarakat Desa Wisata Halal Setanggor ini terlihat dari terlembaganya pertemuan mingguan atau dua mingguan di Setanggor yang isinya membahas pengelolaan desa mereka sebagai destinasi wisata.

Disamping itu, adanya rasa saling percaya yang sudah terjalin dapat menekan biaya pemantauan terhadap orang lain agar orang tersebut berperilaku seperti yang diinginkan dan rasa saling percaya akan memudahkan terjalinnya hubungan kerjasama. Semakin tebal rasa saling percaya, semakin kuat kerjasama yang terbangun antar individu (Vipriyanti, 2007). Untuk melihat suatu bentuk kepercayaan itu berhasil atau tidaknya pada masyarakat desa setanggor bisa dilihat dari partisipasi masyarakat untuk ikut melakukan kegiatan desa wisata halal. Dimana hampir semua masyarakat desa setanggor mendukung kegiatan Desa Wisata Halal Setanggor.

Maka dari itu, sense of belonging yang dimiliki oleh masyarkat desa setanggor kana menciptakan soliadaritas yang kuat pula antar masyarakat. Hal ini tidak terlepas dari terbangunnya rasa kepercayaan di masyarakat dalam hal ini masyarakat antar masayarakat.

\section{Jaringan}

Field (2010) mengungkapkan bahwa modal sosial dapat dimaknai secara sederhana dan diringkas dalam dua kata yaitu soal hubungan. Hubungan ini terbentuk karena pada dasarya setiap manusia 


\section{REFORMASI}

ISSN 2088-7469 (Paper) ISSN 2407-6864 (Online)

Volume 10 Nomor 1 (2020)

berhubungan melalui jaringan yang didalamnya terdapat kesamaan nilai, sejauh jejaring tersebut menjadi sumber daya, dia dapat dipandang sebagai modal.

Jaringan sosial merupakan salah satu fasilitas untuk membentuk kepercayaan dan memperkuat kerjasama dalam suatu masyarakat atau kelompok tertentu melalui bentuk komunikasi ataupun interaksi masyarakat. Masyarakat yang memiliki jaringan sosial yang erat akan memperkuat perasaan kerjasama bagi para anggotanya serta manfaat-manfaat dalam berpartisipasi (Putnam, 1996) dalam Suharto (2005).

Untuk memahami jaringan yang memungkinkan individu mengakses sumber daya dan bekerjasama dalam mencapai tujuan yang sama merupakan bagian penting dari konsep modal sosial. Dimana Putnam (1988) dalam Winarni (2011) membedakannya dengan hubungan formal dan hubungan informal.

Jaringan sosial dalam hubungan formal biasanya seperti yang ada pada kelompok, asosiasi dan sebagainya. Sedangkan jarigan sosial dalam hubungan informal seperti terjadi antara keluarga, tetangga, kerabat dan teman. Struktur jaringan dapat mempengaruhi kualitas hubungan yang terjalin, output yang dihasilkan serta modal sosial yang terbentuk. Kelompok Sadar Wisata (POKDARWIS) SEKARTIJE terbentuk berdasarkan kesamaan orientasi dan kesamaan permasalahan yang dihadapi oleh masyarakat laki-laki didesa setanggor yaitu para petani.

Jaringan sosial dalam pencapaian suatu tujuan tidak terlepas dari kepercayaan. Jaringan sosial sebagai salah satu pilar modal sosial dapat dipahami sebagai hubungan antar sekumpulan orang yang saling terkait baik langsung maupun tidak langsung.

Keadaan jaringan sosial Desa Setanggor dalam melaksanakan aktivitas pariwisata di Desa Wisata Halal Setanggor adalah membentuk jaringan dengan berbagai pihak. Tentu hal ini tidak lepas dari peran Ida Wahyuni selaku pelopor Desa Wisata Halal Setanggor. Ida merupakan Ketua Badan Promosi Parisiwata Daerah Kabupaten Lombok Tengah, maka tidak heran jika sosok Ida Wahyuni memiliki banyak jaringan yang bisa diajak bekerjasama untuk menunjang kegiatan wisata di Desa Wisata Halal Setanggor.

Bentuk jaringan sosial yang ada dalam proses pemberdayaan masyarakat dan pengembangan di Desa Wisata Halal Setanggor, antara lain: (1) Desa Wisata Halal Setanggor dengan Travel Agent. Terkait dengan kepentingan pemasaran selain menggunakan fasilitas internet seperti website, media sosial facebook dan instagram untuk mempromosikan Desa Wisata Halal Setanggor, Desa Wisata Halal Setanggor juga membangun jaringan dengan 11 travel agent dan ada 4 travel agent dari luar negeri. (2) Desa Wisata Halal Setanggor dengan Kementerian Pariwisata. Dalam hal ini Ida wahyuni langsung menghadap ke pusat untuk meminta bantuan terkait kelengkapan fasilitas pada Desa Wisata Halal Setanggor. Bantuan yang diberikan berupa tempat sampah sebanyak 160 buah dan Homestay sebanyak tujuh buah yang mana kini homestay tersebut dikelola oleh BUMDES. (3) Desa Wisata Halal Setanggor dengan ASDP. Jaringan juga terjadi antara masyarakat dengan ASDP. Dalam hal ini jaringan terbangun dengan ASDP yang mana sejak mendengar Desa Setanggor menjadi Desa Wisata Halal, seorang pagawai ASDP yang dulu merasa pernah menggunakan jasa Gendang Beleq dari Desa Setanggor datang dan menawarkan bantuan yang akan ia berikan. Dan kemudian sepakat untuk memberikan bantuan untuk membangunkan sanggar seni di desa setanggor. (4) Pelatihan bahasa Inggris oleh ITDC. Ada pelatihan khusus bahasa inggris yang dilakukan setiap minggu. Jaringan ini bisa terbentuk dari seorang guru yang dulu pernah mengajar disalah satu sekolah di Desa Setanggor, kemudian melihat dan mendengar kini Desa Setanggor menjadi Desa Wisata Halal maka ia berinisiatif mengirim anak buahnya dari Perancis ke desa setanggor untuk memberikan pelatihan setiap minggunya kepada masyarakat di desa setanggor. (5) Desa Wisata Halal Setanggor dengan Balai Wilayah Sungai PU. Kekeringan yang cukup sering dialami oleh masyarakat Desa Wisata Halal Setanggor, bahkan disaat ada wisatawan yang sedang menginap tidak bisa segera mandi karena air yang sedikit, BWS PU memberikan bantuannya dengan membuatkan sumur bor besar sedalam 125 Meter. Hal ini dapat bermanfaat bagi masyarakat Desa setanggor untuk mereka 


\section{REFORMASI}

ISSN 2088-7469 (Paper) ISSN 2407-6864 (Online)

Volume 10 Nomor 1 (2020)

memasak, mandi dan mencuci. (6) Desa Wisata Halal Setanggor dengan Kementerian Desa dan Transmigrasi (KEMENDES). Pelatihan pencelupan benang untuk menambah skill menenun bagi penduduk wanita yang di Desa Setanggor. Hal ini merupakan bentuk pemberdayaan yang diberikan oleh KEMENDES khusus untuk penduduk perempuan di Desa Setanggor guna untuk menambah kemampuan mereka dalam hal menenun. Kegiatan ini sudah rutin berjalan setiap 2 minggu sekali. Yang dulunya menggunakan benang biasa atau sintetis, sekarang bisa menenun dengan kualitas menjadi lebih bagus. Lebih dari itu, bentuk jaringan dari KEMENDES yang lainnya adalah memberikan bantuan homestay dan gallery tenun untuk memajang hasil tenun buatan masyarakat perempuan Desa Setanggor. (7) Desa Wisata Halal Setanggor dengan Perkumpulan Petani Pemakai Air (P3A). Mengingat kini desa setanggor telah menjadi Desa Wisata Halal, sekarang kalau lagi kekeringan, hanya cukup bersurat ke P3A dan melaporkan bagian mana setanggor yang mengalami kekeringan, keesokan harinya pun air sudah mengalir. Kini Desa Setanggor benar-benar diperhatikan oleh Pemerintah setelah menjadi Desa Wisata Halal.

Jaringan sosial yang dibangun oleh ketokohan Ida, membantu sejak awal menghidupkan aktivitas sektor wisata dan menjaga keberlanjutannya melalui promosi dan fasilitasi. Tanpa adanya suatu hubungan atau kemampuan seseorang dalam membangun asosiasi maka modal sosial tidak akan terjadi. Maka dari itu jaringan yang kuat menentukan kuatnya modal sosial.

\section{Norma}

Menurut Plateau (2000) dalam Vipriyanti (2011) mendifinisikan norma sebagai aturan yang menentukan perilaku bersama dalam suatu kelompok individu juga dipahami sebagai prinsip keadilan yang mengarahkan pelaku untuk berperilaku yang tidak mementingkan diri sendiri. Norma akan sangat berperan dalam mengontrol bentuk perilaku yang tumbuh dalam masyarakat sebagai aturan terikat agar dapat mematuhi sesama masyarakat.

Norma yang dibangun dalam kerjasama antar individu di Desa Wisata Halal Setanggor yaitu norma kepercayaan. Untuk menjaga kerjasama itu dibutuhkan norma-norma yang mengikat yang menyangkut hubungan sosial antar masyarakat di desa setanggor, antara lain seperti norma saling tolong menolong untuk memajukan desa wisata mereka secara bersama-sama.

Setiap hubungan yang dibangun antar masyarakat di Desa Setanggor senantiasa memegang prinsip atau aturan, dalam berhubungan menjalin kerjasama dengan orang lain yaitu harus selalu menghormati, menghargai, tidak menyinggung dan tidak membeda-bedakan.

Masyarakat di Desa Setanggor mengutamakan nilai-nilai islam dalam menjalankan desa wisata tersebut, sehingga mereka bisa membentengi efek dan dampak negatif dari kegiatan pariwisata dengan konsep wisata halal, sehingga bisa dikatakan bahwa Desa Setanggor kuat dengan prinsip wisata halalnya.

\section{Dampak bagi Masyarakat Desa Setanggor setelah Desanya Menjadi Salah Satu Desa Wistaa Halal di Lombok}

Desa Wisata Halal Setanggor dibentuk untuk meningkatkan kesejahteraan masyarakat di Desa Setanggor melalui pemberdayaan yang dilakukan. Hal ini dilandasi antara lain karena Desa Setanggor memiliki kekayaan sumber daya alam yang sangat indah, areal persawahan yang luas dan indah serta memiliki kekayaan seni budaya, seperti adanya kelompok gamelan, seni tari dan drama tradisional, dan juga terdapat gong tua yang sudah berumur ratusan tahun yang memang sudah ada di desa tersebut yang merupakan warisan budaya, namun semua itu belum di manfaatkan dengan maksimal.

Desa Setanggor tergolong desa yang kering dan sulit mendapatkan aliran air sehingga sawahsawahnya sulit untuk bisa di tanami pada saat memasuki musim kemarau. Hal ini membuat tidak adanya sumber pemasukan bagi penduduk laki-laki yang mana sebagian besar mata pencahariannya adalah 


\section{REFORMASI}

ISSN 2088-7469 (Paper) ISSN 2407-6864 (Online)

Volume 10 Nomor 1 (2020)

bertani. Sedangkan 80 persen penduduk perempuannya rata-rata memiliki keterampilan menenun kain songket, sehingga membuat kain songket untuk dijual menjadi mata pencaharian mereka.

Namun banyak dari mereka yang sudah berhenti menenun karena kesulitan mencari pembeli yang mau membeli kain tenun buatan mereka. Oleh karena itu, secara keseluruhan dapat dikatakan bahwa Desa Setanggor ini memiliki potensi yang unik, dan daya tarik yang berbeda dengan desa-desa lain pada umumnya.

Melihat segala potensi yang dimilik desa setanggor, membuat Ida Wahyuni ingin mengemas desa ini menjadi sebuah Desa Wisata Halal, yang mana bertujuan untuk mencari alternatif lain untuk meningkatkan perekonomian masyarakat dan melestarikan seni budaya yang memang sudah dimiliki oleh Desa Setanggor.

Segala potensi yang ada di Desa Setanggor diberdayakan untuk menjadi spot wisata yang menarik. Desa Setanggor memiliki 14 Dusun, namun hanya 11 dusun yang telah diberdayakan menjadi spot wisata. Setiap dusun memiliki spot wisata yang berbeda-beda, mulai dari Wisata Religi, Wisata Pertanian yang mana wisatawan akan diajak untuk bercocok tanam maupun memanen hasil padi, Wisata Peternakan yang mana wisatawan akan diajak untuk melihat sekaligus di edukasi untuk mengolah kencing sapi menjadi pupuk, wisata seni budaya, Gallery Tenun dan masih banyak lainnya. Menurut Ida Wahyuni, hingga saat ini sudah lebih dari 39 negara yang sudah datang ketempat Desa Wisata Halal Setanggor dan diperkirakan sekitar 1300 lebih lah wisatawan yang sudah datang. (Wawancara, 2019)

Meskipun pada awalnya niat baik Ida ditentang oleh sebagian masyarakat di Desa Setanggor yang memiliki persepsi bahwa pariwisata hanya akan memberikan dampak negatif pada desa ini karena bisa mempengaruhi budaya lokal dan adat istiadat di desa, serta fikiran masyarakat yang berfikir bahwa desa ini tidak memiliki potensi apapun untuk dijadikan obyek wisata. Namun dengan sosialisasi, edukasi serta berbagai kemudahan dan bantuan yang ditawarkan Ida, lambat laun dapat meyakinkan mayoritas masyarakat Desa Setanggor untuk mejalankan kegiatan pariwisata ini bersama-sama dengan menjadikan desa nya menjadi desa wisata halal.

Sehingga bisa dikatakan bahwa Ida memanfaatkan modal sosial yaitu dukungan semua kalangan, tokoh agama dan adat serta generasi muda untuk bersama-sama mewujudkan Desa Setanggor menjadi suatu desa wisata yang kini dikenal dengan nama Desa Wisata Halal Setanggor.

Tentu saja berdirinya dan berkembanganya Desa Wisata Halal Setanggor ini tidak lepas dari pemberdayaan masyarakat. Keberhasilan yang terjadi di Desa Setanggor Kabupaten Lombok Tengah dalam memberdayakan masyarakat melalui berbagai dinamika modal sosial yaitu antara lain kepercayaan, jaringan sosial, dan norma.

Terdapat beberapa dampak positif yang bisa dirasakan masyarakat Desa Setanggor setelah desanya menjadi salah satu Desa Wisata Halal di Lombok, antara lain:

1. Mengurangi tingkat pengangguran musiman terutama ketika musim kemarau. Dulunya penduduk laki-laki hanya menganggur kalau musim kemarau karena sawahnya tidak bisa ditanami, tetapi sekarang mereka tetap bisa beraktivitas karena ada wisatawan yang terus datang. Misalnya jika ada wisatawan yang datang pada saat musim kemarau dan sawah-sawah mereka kering, mereka bisa mengajak wisatawan untuk mengunjungi spot petik buah dan peternakan. Sehingga bisa dikatakan bahwa mereka tidak lagi menganggur karena adanya alternatif mata pencaharian tambahan bagi mereka.

2. Kekeringan tanah persawahan yang biasanya dirasakan masyarakat Desa Setanggor sudah tidak dirasakan lagi. Kini Desa Setanggor lebih diperhatikan oleh Pemerintah dan dari Perkumpulan Petani Pemakai Air (P3A) dikarenakan Desa Setanggor juga menjadikan keindahan alamnya sebagai produk wisata sehingga bisa dikatakan akses pengairan Desa Setanggor menjadi lancar. Jika terjadi 


\section{REFORMASI}

ISSN 2088-7469 (Paper) ISSN 2407-6864 (Online)

Volume 10 Nomor 1 (2020)

kekeringan, masyarakat Desa Setanggor hanya perlu bersurat ke Bupati dan P3A untuk mohon segera di airi, sehingga besoknya biasanya langsung ada air yang mengalir.

3. Menghidupkan kembali kegiatan ekonomi perempuan penenun, Masyarakat perempuan yang dulunya menenun dan kemudian berhenti, sekarang kembali menenun lagi. Malah bisa dikatakan bahwa mereka kewalahan dalam menerima pesanan dari wisatawan. Mereka kini juga tidak kesulitan mencari pembeli karena hasil tenun mereka langsung bisa mereka pajang di gallery tenun di Desa Wisata Halal Setanggor. Berdasarkan wawancara yang peneliti lakukan juga bahwa kain tenun dari Desa Setanggor ini sedang ada pesanan 80 lembar kain tenun dari designer di Jakarta.

4. Menghidupkan kembali alat transportasi lokal ramah lingkungan yakni cidomo. Dengan dijadikannya Desa Wisata Halal Setanggor turut menghidupkan kembali "cidomo" (alat transportasi lokal lombok) yang dulunya mati karena sudah tidak diminati lagi. Sekarang semenjak menjadi desa wisata halal, akhirnya cidomo-cidomo mereka mulai aktif kembali digunakan untuk transportasi para wisatawan yang digunakan dari spot satu ke spot yang lainnya atau hanya untuk sekedar berkeliling di Desa Setanggor.

5. Semenjak menjadi desa wisata halal, Setanggor mendapat berbagai bantuan berupa perbaikan fasilitas umum seperti jalan, penerangan, dan sumur bor besar yang bisa memberikan air bersih untuk beberapa dusun

6. Membuka interaksi masyarakat Desa Setanggor dengan dunia luar terutama wisatawan mancanegara, sekaligus dapat memperkenalkan definisi "halal" yang sesungguhnya, sehingga wisatawan mancanegara tidak lagi salah persepsi terkait konsep wisata halal.

Sedangkan, jika berbicara dampak negatif dari kegiatan Desa Wisata Halal Setanggor sejauh ini bisa dikatakan tidak ada, karena dampak negatif yang ditakutkan terjadi bisa terkontrol dengan konsep halal yang menjadi prinsip dalam pengelolaannya. Bahkan sejauh ini, wisatawan mancanegara yang datang ke Desa Wisata Halal Setanggor mengaku sangat menyukai Desa Wisata Halal Setanggor dan sama sekali tidak keberatan untuk tidak menggunakan pakaian mini. Bahkan mereka sering meminta untuk ikut memakai sarung dan meminta untuk dijelaskan gerakan-gerakan solat. Dan cukup banyak wisatawan yang selalu repeat order untuk datang ke Desa Wisata Halal Setanggor.

Berdasarkan uraian diatas membuktikan bahwa modal sosial dapat menjadi solusi dalam memecahkan permasalahan yang ada di masyarakat desa setanggor melalui pemberdayaan masyarakat. Pemberdayaan yang berhasil dilakukan dapat menciptakan mata pencaharian tambahan bagi masyarakat disana. Yang mana bisa menambah pemasukan bagi mereka saat musim kemarau tiba.

Maka dari itu, dengan adanya modal sosial yang kuat masyarakat dapat bersama-sama memecahkan permasalahannya dan bergerak bersama dalam membangun daerahnya. Sehingga hal itu dapat mengentas kemiskinan yang ada serta mensejahterakan masyarakat itu sendiri.

\section{PENUTUP}

Berhasilnya pemberdayaan yang terjadi di Desa Setanggor, menciptakan aktivitas ekonomi baru yang dikemas menjadi Desa Wisata Halal, yang mana keberadaannya dapat berkontribusi dalam meningkatkan kesejahteraan masyarakat yaitu dengan tersedianya pekerjaan alternatif bagi masyarakat, kembali hidupnya alat transportasi lokal ramah lingkungan yakni cidomo dan berdayanya masyarakat perempuan dalam menenun khas lokal. Meskipun pada awalnya ide desa wisata halal menimbulkan pro dan kontra. Namun dengan kuatnya modal sosial yang dimiliki oleh komunitas Desa Setanggor mampu mengatasi permasalahan yang terjadi. Keberhasilan Setanggor dalam memberdayakan masyarakatnya, melalui sejumlah dinamika modal sosial. Modal sosial yang ditemui tersebut berupa kepercayaan, jaringan sosial dan norma. Kepercayaan terbangun karena melihat hasil nyata dari ide yang digagas oleh 


\section{REFORMASI}

ISSN 2088-7469 (Paper) ISSN 2407-6864 (Online)

Volume 10 Nomor 1 (2020)

Ida Wahyuni serta melihat ketokohan atau sosok seorang Ida Wahyuni. Yang kedua jaringan sosial yang kuat yang dimanfaatkan dalam proses sosialisasi dan pemberdayaan pada masyarakat yang sejak awal membantu menghidupkan aktivitas desa wisata halal setanggor dan menjaga keberlanjutannya melalui promosi dan fasilitasi. Ketiga, norma kepercayaan yang dapat menjadi pedoman dalam kerjasama antar individu di Desa Wisata Halal Setanggor dan memegang nilai-nilai islam dalam menjalankan desa wisata halal setanggor sehingga dapat membentengi dampak negatif dari kegiatan pariwisata dengan konsep wisata halal. Oleh karena itu dapat dikatakan bahwa pemberdayaan akan berhasil jika suatu komunitas nya kuat yaitu memiliki kepercayaan, jaringan sosial dan norma yang dipegang teguh.

\section{DAFTAR PUSTAKA}

Creswell, J. W. 2010. Researh Design: Pendekatan Kualitatif, Kuantitatif dan Mixed. Yogyakarta: PT Pustaka Pelajar.

Field, J. 2010. Modal Sosial (Alih bahasa dari bahasa Inggris oleh Nurhadi). Bantul: Kreasi Wacana.

Fukuyama, F. 2002. Trust: Kebijakan Sosial dan Penciptaan Kemakmuran. Yogyakarta: Penerbit Qalam.

Miles, M. B, Huberman, A. M, dan Saldana, J. 2014. Qualitative Data Analysis, A Methods Sourcebook, Edition 3. USA: Sage Publication. Terjemahan Tjetjep Rohidi, UI-Press.

Satria, Dias. 2008. Modal Manusia dan Globalisasi: Peran Subsidi Pendidikan. Faculty of Economics Brawijaya Malang.

Sugiyono. 2009. Metode Penelitian Kuantitatif Kualitatif. CV. Alfabeta: Bandung.

Suharto, Edi. 2005. Membangun Masyarakat Memberdayakan Rakyat. Kajian Strategis Pembangunan Kesejahteraan Sosial dan Pekerjaan Sosial. Bandung: PT. Refika Aditama.

Strauss, A \& Corbin, J. 2003. Dasar-dasar Penelitian Kualitatif. Yogyakarta: Pustaka Pelajar.

Syahyuti. 2008. Peran Modal Sosial (Social Capital) dalam Perdagangan Hasil Pertanian. Forum Penelitian Agro Ekonomi Volume 26 No.1, Juli 2008.

Vipriyanti, N. U. 2007. Analisis Keterkaitan Modal Sosial dan Pembangunan Ekonomi Wilayah: Studi Kasus di Empat Kabupaten di Bali (draf disertasi). Bogor. Sekolah Pascasarjana Sosiologi (S3) Universitas Negeri Makassar. 2011. Modal Sosial dan Pembangunan Wilayah. Malang: UB Press.

Winarni, I. 2011. Keterkaitan Antara Modal Sosial dengan Produktivitas pada Sentra Bawang Merah di Kecamatan Pangelangan Kabupaten Bandung. Tesis. Jakarta: Program Magister Perencanaan dan Kebijakan Publik Universitas Indonesia Salemba.

Yuliarmi N. 2011. Peran Pemerintah, Lembaga Adat Dan Modal Sosial Dalam

Pemberdayaan Industri Kecil Dan Menengah (Studi Pada Industri Kerajinan Di Provinsi Bali). Disertasi. Program Doktor Ilmu Ekonomi Pascasarjana, Fakultas Ekonomi \& Bisnis, Universitas Brawijaya, Malang.

Yustika, Ahmad Ernani. 2008. Ekonomi Kelembagaan, Definisi, Teori dan Strategi. Malang: Banyumedia Publishing. Penerbit Erlangga. 